\title{
Love Language in Social Leadership: Teacher, Student, Parent, Politician and Church
}

\author{
Elymar A. Pascual, Grace Ann A. Gadlan, Margarita C. Bugia, Jr., \\ Eunice G. Suazo, Jericson B. Burbos \\ elymarpascual@rocketmail.com \\ Department of Education, Nagcarlan, Laguna, Philippines, 4002
}

\begin{abstract}
This article focused on knowing the love language of leaders at various levels and on helping to motivate the leaders of Nagcarlan, Laguna, Philippines. From the many aspects of social leadership, five were selected - Teachers, Student, Parent, Politician and Church. Survey questions were distributed to selected leaders to conduct this research. The researchers went to Brgy. Sta. Lucia, Talangan, Yukos, Alibumbungan, Malinao, Arela, Poblacion and Talangan Integrated National High School - thirty in all were interviewed by the researchers. In all aspects of leadership, it was found that there is the highest number who desire the love language through meaningful time, there is average number for those who desire practical Service, the number is not so great for those who desire physical, and lowest count for loving the love language by the word of affirmation. Using the mean and standard deviation for the pre- and post-survey results of the researchers, it was found in the pre-survey that there was a mean of 4.08 which means that the response of the respondents had a high level in all indicators, and with $1.09 \mathrm{sd}$ states that there is a distance in every answer of the respondents interviewed by the researchers. For the post-survey, it has a mean of 4.26 which means that the response of the respondents to all indicators was very high. This in turn has an sd of 0.89 which indicates that respondents' answers were close. Eventually, it was suggested to leaders in various aspects to learn, appreciate, and expand their knowledge about love language so that they would have an idea of how they could further develop their personality when it comes to leadership. In conjunction with this, the authors also left a suggestion to subsequent researchers.
\end{abstract}

Keywords: love language; teacher; student; parent; community; religion; leader

\section{Introduction}

"When the emotional tank is low, feelings of love go away."

\section{Gary Chapman}

A person who is not filled with love, cannot give love for others. Also, the stoning or loss of concern of one person for other can also cause the loss of care for him by other people around him. With that being said, analyzing love language can help an individual to know the things he value when his neighbor feels love for him.

Each individual has their own way in valuing the people they love. There are some who's willing to spend more significant time with their loved one. Others want to receive even a simple gift because they give value for the things they receive despite of how big or small it is. For some, one of the things they value is to receive a word/s of admiration, whether written or verbal speaking. There are also people that want to be given service because they think it show or proves love of someone. And others want to feel physical touch for the reason that it makes them feel loved by their partner in life.

It can be said that people have their own love language, and even though they are different, they still want one thing - to feel the love of the people around them. The diversity of the language shows the uniqueness of each person. Indeed, God created us differently on our own. 


\subsection{Background of the Study}

Having a leader in a country is a great help to have peace and order on everyone, but the people will be more helpful if all the effort of the leaders are given importance. According to V. Diccicion, "no power is greater than love". But how can a town or barangay be developed if the leaders in the area do not feel the love of their jurisdiction? They have the power to perform for each other, the community will be more prosperous when affection that intercedes and led. The people must show love to the leader and solidarity of the occurrence or project in society.

This study was selected to conduct in the municipality of Nagcarlan, province of Laguna. The municipality of Nagcarlan is made up of 52 barangays and from 52 barangays, the researcher chooses 8 places where this study will be conducted. The 8 places chosen are the barangay of Talangan, Sta. Lucia, Arela, Yukos, Malinao, Alibumbungan, Poblacion and Talangan Integrated National High School. This letter was formed due to the call of social leadership and because of the concerns of researchers in the leaders.

\subsection{Theoretical Framework}

In Gary Chapman's book entitled "The Five Love Language", it gives answered on how to inflict love to the others in a better way. The five love language according to Gary Chapman are word of affirmation, quality time, receiving gifts, acts of service and physical touch. This book also said the theory in which an individual has the main and second love language. Gary Chapman gave his own viewpoint on how to acknowledge the love language of the other person. The love language of someone can be observe on how this person felt the love from someone and analyze it on what was that person pinpoint when they in love.

Word of Affirmation is a love language that states that actions or moves did not always provide good messages or means. It is better for this love language if the word was written or spoken by someone. People who have this love languages emphasize the complements come from the people around them and by this way, they felt that they are loved by someone. The complements give them motivation for life, while the indignity they receive are not immediately forgotten because for them it indicates their weakness.

Quality Time is the love language that refers to the appreciation of the unpopular attention of another person. It says that the love language requires intensive conversation or story. Here, the two individuals talk about to each other, looking eyes and almost no one distracts to their conversation. This is the main language of many people. If they are not given attention, they can say that they are not loved by those who are around them.

Receiving Gifts is a love language associated with one person's materialism, but in a positive perspective. People with this love language appreciate not just the material things given to them, but the effort of the person who gave it, and the meaning of the gift given to them. Through the gift, they felt that a person knows them, caring for them, and they are important because simple gifts given to them are like little sacrifice from the people around them. They feel that they are not love when the people around them forget the special days in their lives. Giving a simple gift signify as a representation of love that will be appreciated by the receiver.

Acts of Service this love language values the matter or service that will be enjoy by the person. It is said to be the opposite of the Word of Affirmation because the person who has this love language wants to be more expressive by an action than words. Instead of complements, they give much importance to the action or help from the others even in simple things. The service that had been given to them without any condition boost their emotion because they felt that they are love by the person when they are help by the others on their activities.

Physical Touch is a love language that values simple comparatives or caring from the others, because even it is just simple action, they feel that someone loves them. Simple protection can get the full attention of people with this kind of love language. They value every moment wherein someone hold their 
hands, put hands on their shoulder or even behind. In this way, they feel that other people love them. If in every touch shows love, the weighted emotion of the person with this kind of love language relieved. This is the strongest love language because when a crisis comes to people who love, the feeling of love is more dominant. When unexpected events come, the only thing that the person can do if their love ones are crying was to hold their hand and give them a hug because "in a time of crisis, a hug is worth more than a thousand words."

\subsection{Conceptual Framework}

Presented below is the paradigm in this study wherein it was in Input-Process-Output (I-P-O) format.

Input Process Output

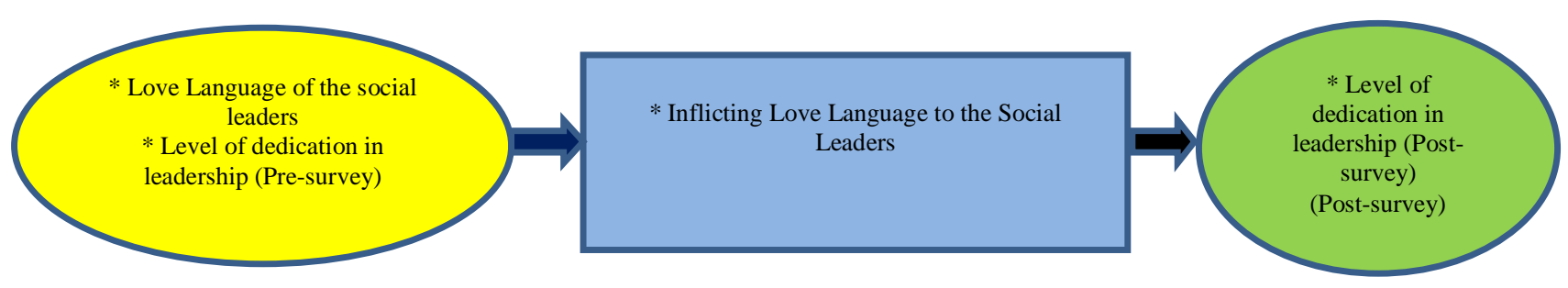

Fig. 1. The paradigm of the study

For introductory of this study the researcher presents their finding in the Input. They acknowledged the love language of social leaders through a questionnaire. Also, they also acknowledged their level of dedication to leadership. After finding their love language and level of dedication to leadership, researchers provide an action to inflict to the social leaders that had been interviewed with accordance to the love language they have, and this was indicated in the Process. And last, researchers acknowledge the level of dedication to the leadership of interviewees to see if the level of dedication in leadership was increased or remained at the previous level, and this is the content of the output.

\subsection{Statements of the Problem} leadership.

The aim of this study is to know if the love language helps the social leader's dedication level in

If given an opportunity to discuss one by one, the following are the questions desired by this study:

- What is the love language of the social leaders:
a. Teachers;
b. Students;
c. Parents;
d. Politicians;
e. Religious group leaders?

- What is the social leader's level of dedication in leadership before inflicting the love language?

- What is the social leader's level of dedication in leadership after inflicting the love language?

- Is love language help the social leaders in increasing the level of their dedication in leadership? 


\subsection{Scope and Limitations of the Study}

In the study, the researchers went to various barangays in Nagcarlan town, province of Laguna, to gather data and information about the love language of social leaders. The people involved in this study were teachers, students, parents, politicians and church leaders. The researchers administered the survey question to six individuals per leadership category, with a total of thirty people. The data and information they gathered gave meaning and significance to their study. In this writing, the researchers devoted enough time and preparation in order to finish the said study. The time and period set by the developers of the Language Month Program in the Nagcarlan District was sufficient to search and find accurate and reliable information that could be processed by the researchers.

\section{Related Literature}

As Bennis (2016) wrote titled "On Becoming a Leader", "you don’t have to be gifted or to be born lucky with the ability to lead; you can learn it". It is not easy but it can be learned. He also shared five important things that need to be learned in leadership; (1) Guiding vision or dream, (2) passion or affection, (3) integrity, (4) confidence and (5) curiosity and courage.

"Leadership is not just about power and honor, but a duty and responsibility in every person under the management of a leader", these are just a few of the words left by Adel A. Tamano (2009). Based on his experience, he shared three things of a true and honest leaders must possess: (1) know the constituency, (2) have a vison, and (3) be a staunch opponent of corruption.

Dela Peña (2011) adds that when a leadership is compared to a dance, "it takes two to tango". This means that in a leadership, it cannot be just leaders acting but also requires the participation of the constituents. Through the positive thinking and behavior of the leaders, they can help the constituents, and this can be said to be an important ingredient for the projects to be successful.

The constituents will not be well if the leader does not possess the appropriate qualities. An individual like him can even form a good leader if he keeps his service in mind and heart. Economic development depends on a leader is his leadership is used correctly and he can influence other people around, according to Atienza (2014).

From Rivera's study (2012), leadership is a process by which an individual can effectively persuades other individuals to accomplish a goal. Leadership is studied but the personal characteristics of a leader such as his ability and knowledge are can be influenced by his personal beliefs, esteem, ethics and character. The knowledge is directly contributes to the leadership process, while the characteristics of a leader gives him a unique character that separates him from others.

In connection with other study for social leadership, Brother Gus Boquer, the very kind president of the De La Salle University and Science Institute in Dasmariñas Cavite offered a book, "Lessons I've Learned" for school leaders. According to him, a leader should know how to fix a problem without other people stepping on it. It is important for the leader to consider how each individual feels, whether each step he/she takes is harmful or beneficial because he/she can be said to be considered a model by those around him/her.

According to Kelly Hurliman, in the book "The 5 Love Languages about Gary Chapman", in knowing the five love languages changed his life. It changes their married life. He said that the message of the book he read was simple but in his opinion, it was very powerful. It can be seen in Chapman's writing that he had a lot of experience in using the love language. Thus, what Chapman wrote helped him and his relationship with his wife.

"In having specific love language already doesn't mean that you need to forget that other love languages", Chapman said (2008). Because learning other love languages, our relationship with other people will be even stronger.

"Love language is not just for relationships", Chapman said (2010). It can also be used in other 
aspects - in school management, home, and church and even in government.

"Death and life are in the power of the tongue; and those who will love it, thereof shall eat the fruit." Proverbs 18:21. Most people in a relationship do not realize the good help of giving or saying good compliments to others. This is one of the powerful things that can help in showing love.

According to Chapman (2015), "Feeling and showing love in various ways as well as practicing it can help a relationship". Thereof, the five love languages must be known in order to fully express love to one's spouse and to other people around.

"Love is about giving things that you can do or you can give to others, not just giving them to yourself", said Dr. Gary Chapman. With that being said, to know the love languages of every person can really help each one another to determine the things we should do for them so that they can feel our care.

\section{Research Design}

This study used descriptive research design. According to Blay (2013), this design is appropriate for studies that use a questionnaire and analyzing the interviewee's answers to come to a conclusion. In this study, the researchers used questionnaires on the love language and level of leadership dedication to find out the answer to the problem that was created at the beginning of the research.

\subsection{Population}

The number of respondents in each barangay can be seen in the table below.

Table 1. Number of respondents in each barangay

\begin{tabular}{|l|c|c|c|c|c|c|}
\hline Barangay/Place & Teacher & Student & Parents & Politician & $\begin{array}{c}\text { Church } \\
\text { Leader }\end{array}$ & Total \\
\hline Talangan & & 2 & 1 & 2 & 1 & 6 \\
\hline Sta. Lucia & & & 1 & 1 & 1 & 3 \\
\hline Alibumbungan & & 1 & & 1 & & 2 \\
\hline Yukos & & & 2 & 2 & 3 & 7 \\
\hline Poblacion & & 2 & 2 & & & 4 \\
\hline Malinao & 1 & & & & & 1 \\
\hline Arela & 1 & & & & & 1 \\
\hline TINHS & 4 & 1 & & & $\mathbf{6}$ & $\mathbf{3 0}$ \\
\hline Total & $\mathbf{6}$ & $\mathbf{6}$ & $\mathbf{6}$ & $\mathbf{6}$ & & \\
\hline
\end{tabular}

The table shows the number of leaders in each Barangay of Nagcarlan who responded to the survey regarding their love language and level of dedication to leadership.

\subsection{Data Collection Methods}

The flowchart shows the step-by-step process of finding an answer to the problems presented in the first part of the study 


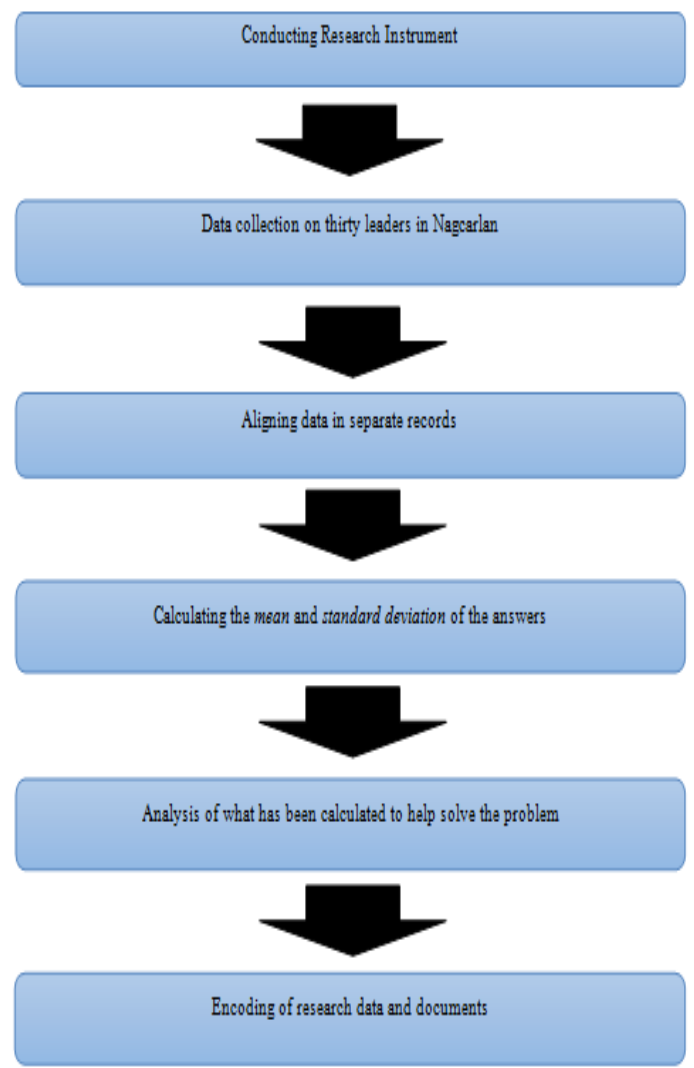

Fig. 2. Flowchart of data collection

\section{Data Presentation, Analysis and Interpretation}

This chapter is concerned with data presentation of the findings through the study.

\subsection{Language of Love of Social Leaders}

The bar graph on the next page shows the Love Language of teachers. In six teachers from Arela, Malinao at Talangan Integrated National High School, one of them feels love when she receives letters or words of affirmation; four of them feel love when they are given quality time, and one feels love when shown love or appreciation through a soft cares or a kind of physical touch. They do not pay attention to the gifts they receive that are sometimes bribes in the eyes of others. They frequently prefer to provide assistance to their students by conveying or sharing knowledge. 


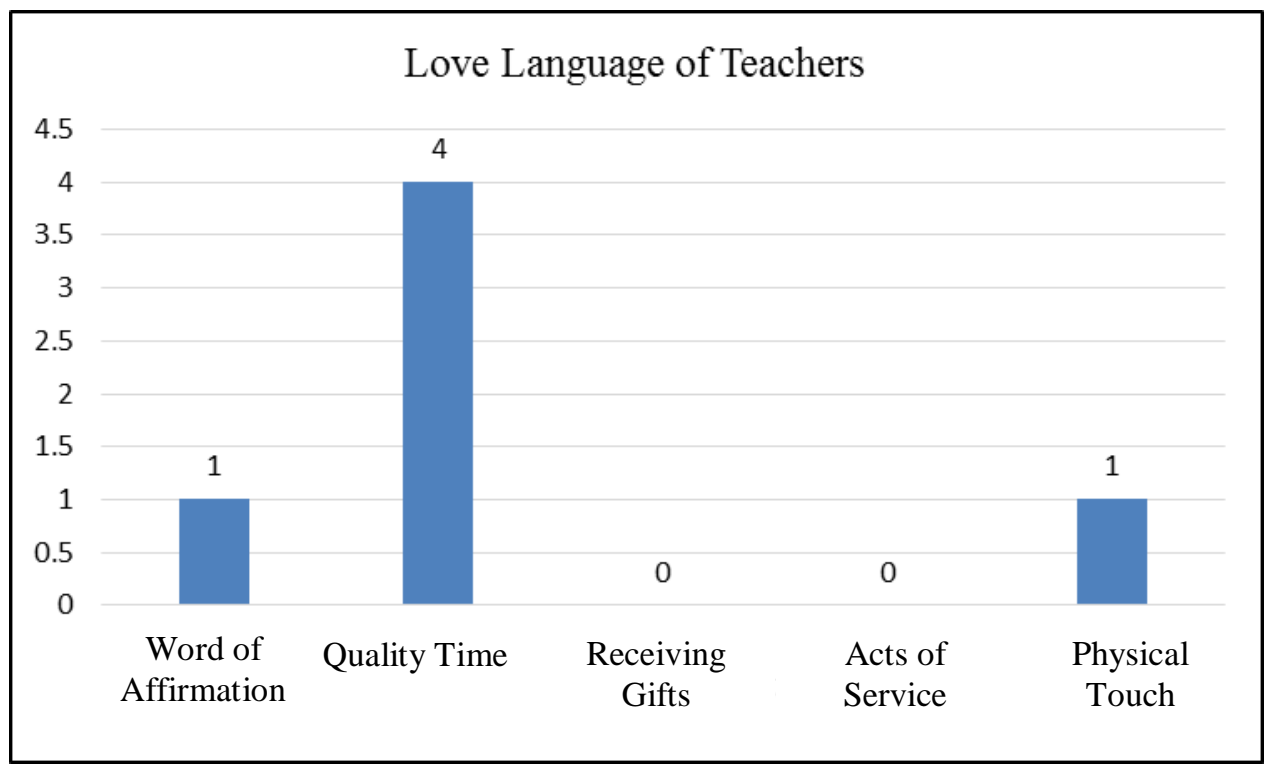

Fig. 3. Love language of teachers

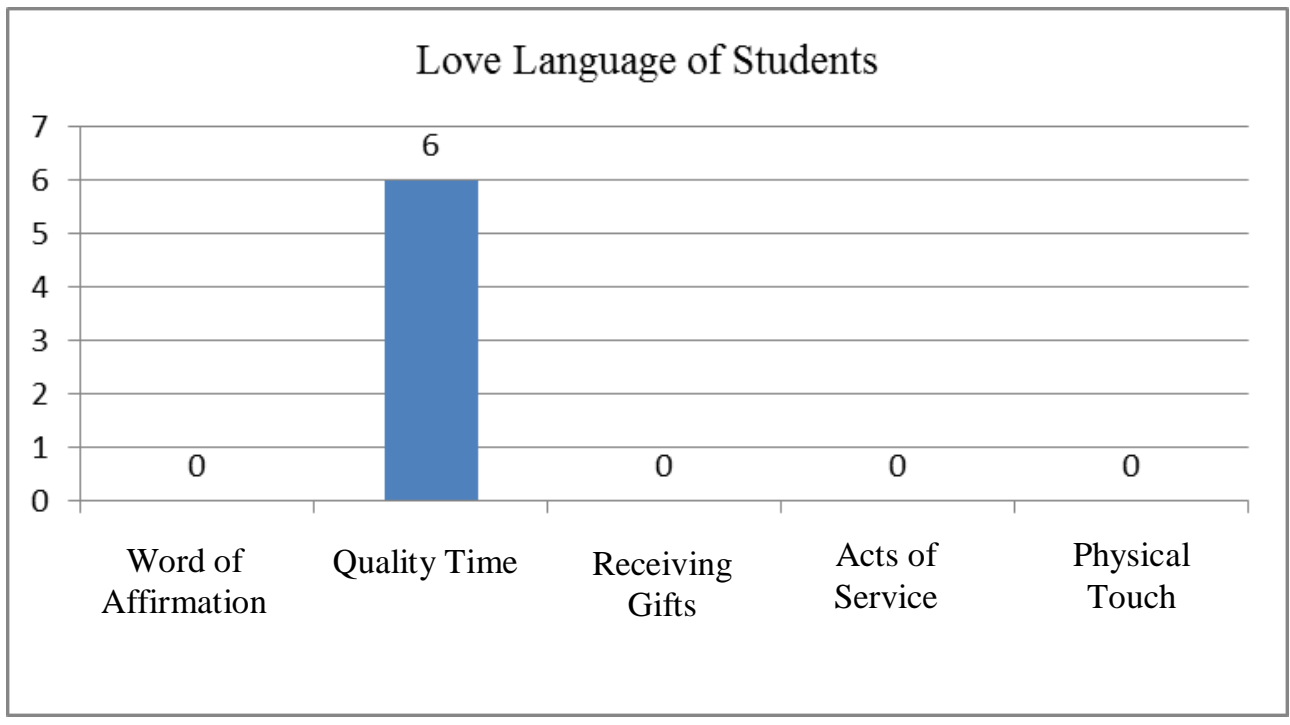

Fig. 4. Love language of students

The bar graph above shows that the lead students were more interested in meaningful time because of the six interviewed, all said their love language was quality time. They prefer giving them time from their neighbor than words of affirmation, receiving a gift, acts of service, and a physical touch. 


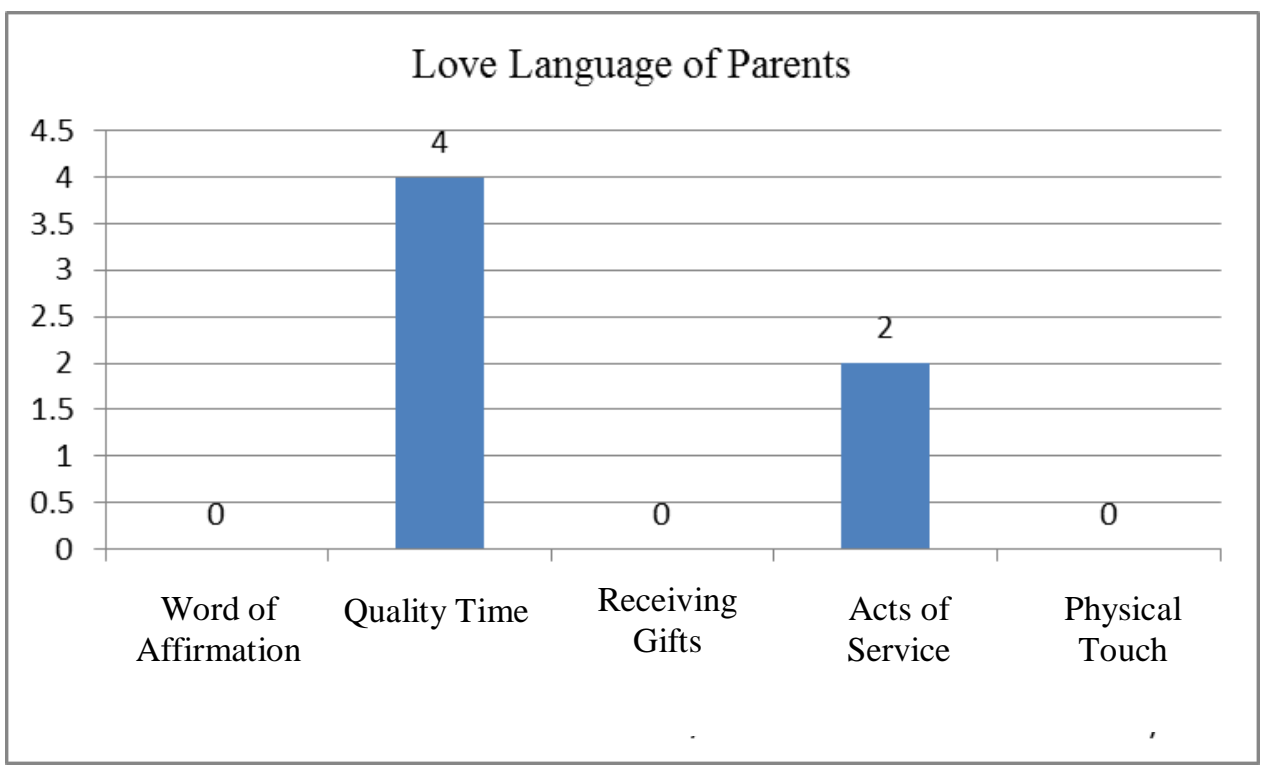

Fig. 5. Love language of parents

The bar graph above shows Love Language of Parents in Nagcarlan. Four of the six parents interviewed by the researchers feel love when they are given meaningful time and two desire acts of service similar to just helping them with house chores as the love language. They don't need to rely on words of affirmation to meet a parent's responsibility, as well as receiving gifts and physical touch.

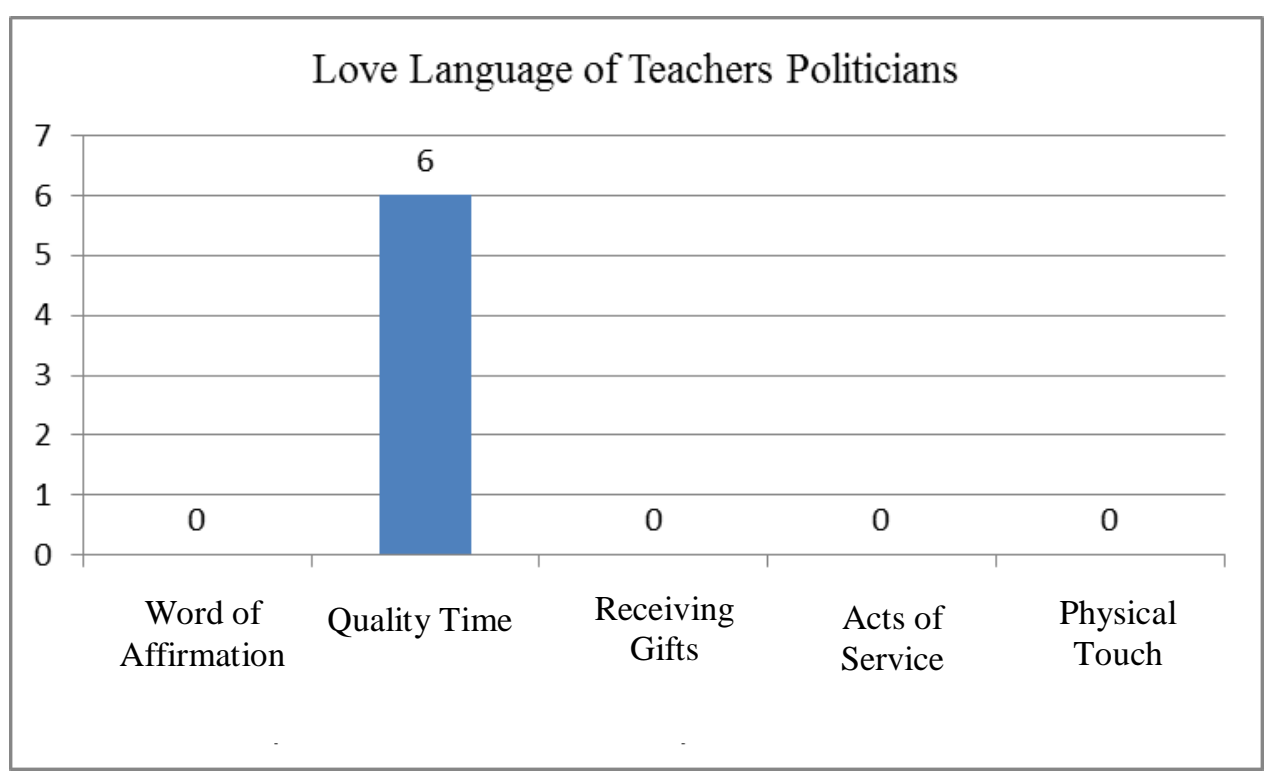

Fig. 6. Love language of politicians 
The bar graph in the previous page shows the Love Language of Politicians. The researchers interviewed six politicians in Nagcarlan, they all feel love when they were given valuable time. Politicians are very good at talking to a lot of people, and they get excited when someone listens and gives time to their challenges and promises. They become enthusiastic when the people around are willing to give time for them to listen. Sometimes, they do not care what the people around them say, so they just serve with full dedication, no matter what people say to them, whether it's admiration or criticism. They also avoid receiving gifts to avoid disgracing their image. They are the providers and they are not the ones being served. Because they really shake hands with a lot of people, they no longer pay attention to the people who shake hands with them as a sign of admiration, because they are the ones who really reach out to the people.

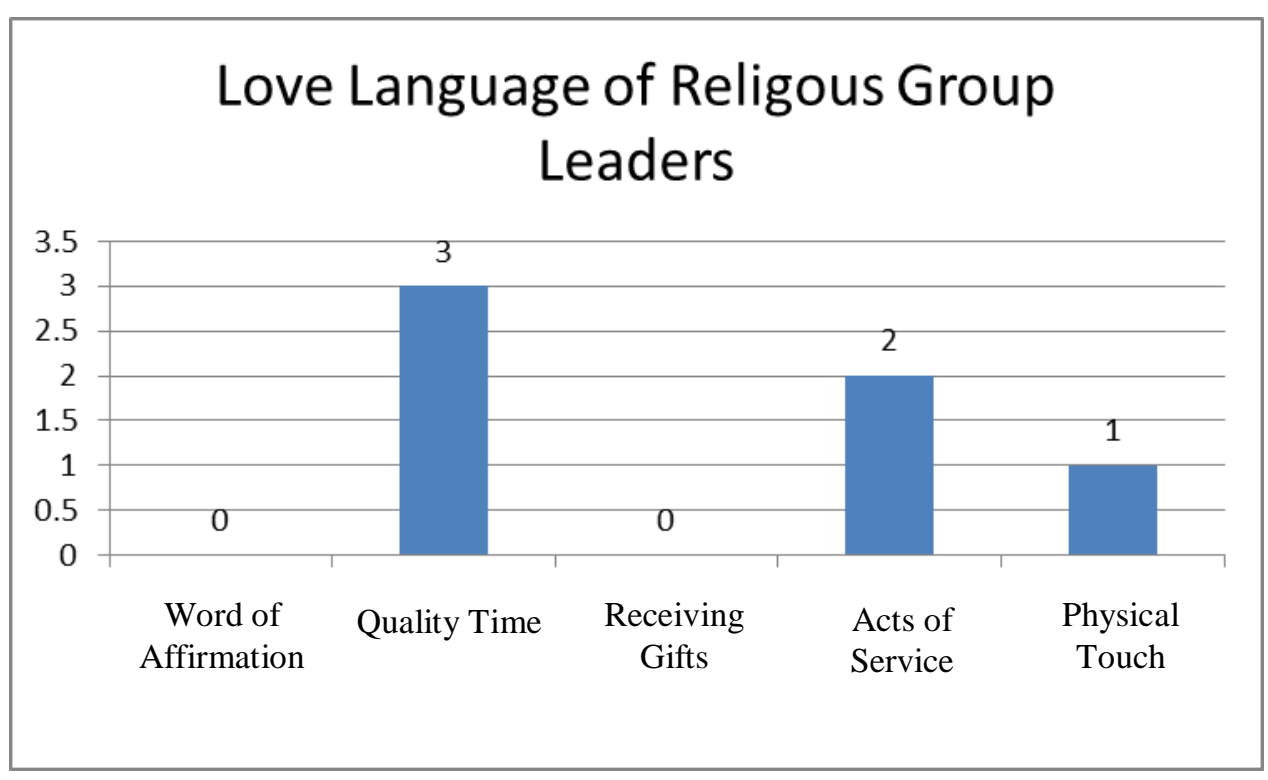

Fig. 6. Love language of religious group leaders

The bar graph above shows that 3 out of 6 religious group leaders are united in the love language by devoting time or quality time and 2 want acts of service while one wants a soft cares like physical touch as the love language. None of the six interviewees can be seen to have the love language through words of affirmation as well as receiving gifts. Perhaps this is because religious group leaders need people who will also listen to them despite all that they do, who will help them with church activities, and people who will feel love through a physical touch like tap on their shoulder.

The pie graph in the next page shows the leaders of teachers, students, parents, politicians, and even the religious group leaders with a total of 30 . And 23 of them are desire that their love language are having a quality time, them 4 of them feel loved when someone is through act of service, 2 of them is through physical touch, and the remaining one is feel loved through the word of affirmation. Of the thirty interviewees none wanted the love language by accepting a gift. This shows that leaders are more willing to spend significant time with them than the other mentioned. 


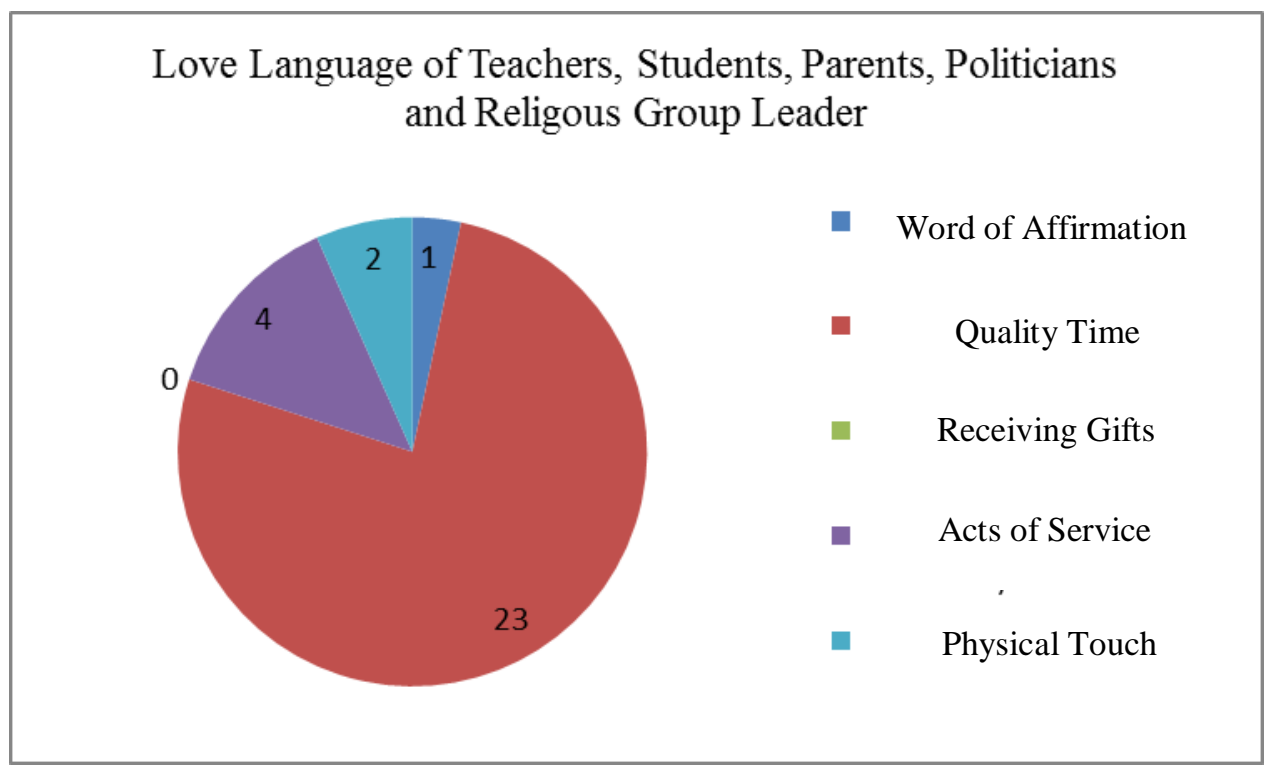

Fig. 7. Love language of social leaders

\subsection{Level of Dedication in Leadership (Pre-Survey)}

Table 2. Mean level of dedication in leadership (pre-survey)

\begin{tabular}{|c|c|c|c|}
\hline Indicators & Mn & SD & Interpretation \\
\hline 1. I am doing my duty to the best of my ability. & 4.23 & 1.04 & Very High Level \\
\hline 2. I have an appreciation for the role or calling that God has given me. & 4.47 & 0.97 & Very High Level \\
\hline 3. I want to help others as much as I can in times of need. & 4.37 & 1.10 & Very High Level \\
\hline 4. I am focused on my role or task and nothing else can be a distraction. & 3.87 & 0.94 & High Level \\
\hline $\begin{array}{l}\text { 5. I like to participate in meeting or gatherings where important things are } \\
\text { discussed. }\end{array}$ & 4.17 & 1.05 & High Level \\
\hline 6. I have joy in fulfilling my duties. & 4.27 & 1.05 & Very High Level \\
\hline $\begin{array}{l}\text { 7. I am contented with what I receive from my family, organization or } \\
\text { government. }\end{array}$ & 4.07 & 1.28 & High Level \\
\hline 8. I can live well as a member of the community. & 4.27 & 1.08 & Very High Level \\
\hline 9. I can express sufficiency in my life. & 3.97 & 1.10 & High Level \\
\hline 10. I have basic needs in life. & 3.97 & 1.22 & High Level \\
\hline 11. I am having personal growth. & 4.00 & 1.05 & High Level \\
\hline 12. I think I am becoming a model to my colleagues. & 3.60 & 1.10 & High Level \\
\hline 13. You can see a good outlook of life through me. & 3.97 & 1.00 & High level \\
\hline 14. I am becoming a role model to other people in our community. & 3.83 & 1.12 & High Level \\
\hline 15. I have high dignity in life and I am maintaining it. & 4.23 & 1.22 & Very High Level \\
\hline Average & 4.08 & 1.09 & High Level \\
\hline
\end{tabular}

Legend:
4.21-5.00 Very High Level
3.41-4.20 High Level
2.61-3.40 Average Level
1.81-2.60 Low Level
1.00-1.80 Very Low Level

According to the table, the performance of the 30 leaders interviewed at their best is at a very high 
level (4.23), and it has a standard deviation of 1.04. This SD states that the answers of the interviewees are distant from each other. This may be because they are in different areas of leadership. Their very high score in this part means they are dedicated to their role.

The following number in the table shows that the appreciation of the 30 leaders interviewed for the role or part given to them by God was at a very high level (4.47), and this in turn had a standard deviation of 0.97. This SD states that the answers of the interviewees are close to each other. This is possibly because they believe that leadership is a gift from God to them. The resulting very high score in this part means that they fully accept the role or part given to them by God.

According to the next number in the table, the leaders have a very high level of dedication (4.37) and a standard deviation of 1.10. This SD means that their answers are already far apart. However, we can say that the 30 leaders interviewed have a desire to help others as much as they can in times of need.

The fourth number in the record states that 30 leaders are focused on their roles and says they have a high level of dedication (3.87) and have a standard deviation of 0.94. This SD states that the answers of the interviewees are close to each other. Leaders are focused on their roles and are not intimidated because they know they are committed to their leadership. The high score in this part says that no one will interfere with their good doing.

Also, according to the record, the 30 interviewees wanted to join the meetings or gatherings as long as the topic was important and indicated that they had a high level in this area (4.17), and it had a standard deviation. at 1.05. This SD states that the answers of the interviewees are far apart. This is likely to happen because they have different preferences and decisions about attending a meeting. A high score in this area means they want to listen to the meetings although some have other things to focus on in their leadership.

In the following number it can be seen that the joy of the interviewees fulfilling their role has a very high level (4.27) and has a standard deviation of 1.05 which says that their answers are at a distance from each other which probably happened. for the reason that they have different ways of leading and fulfilling their duty. The very high score proves that such leaders have joy in fulfilling their duties.

The seventh number in the table shows that the interviewed leaders have a high level (4.07) which means they are content with what they receive from their family, organization, or government. This, in turn, has a standard deviation of 1.28 which states that their answers have a distant relationship with each other that may have occurred because they have different interactions with the family, organization, or government.

Table number eight shows that the lifestyle of the interviewed leaders has a very high level (4.27) and they also have a well -established lifestyle as a member of a community. The number eight also has a standard deviation of 1.08 which says that their answers are far apart because they have different lifestyles in a community.

From the record number nine, it can be seen that the expression of the 30 leaders interviewed of their adequacy of life is at a high level (3.97) and this in turn has a standard deviation of 1.10. This SD shows that their answers have a distant relationship with each other in expressing their sufficiency in life. This may be the result because they are in different walks of life. A high score in this section proves that they have a desire to express sufficiency in their lives.

The number of ten in the table shows that the interviewees have a high level of dedication (3.97) due to having basic life needs, and this in turn has a standard deviation of 1.22. This SD states that the respondents' answers were distant from each other. This is likely to happen because they have different life needs that they can use to lead. The high score that resulted in this section means that the interviewed leaders are developing and getting their basic life needs.

According to the table above the subsequent number, the thirty leaders interviewed experience personal growth and have a high level (4.00) which means the development of their own leadership skills is what they feel. This, in turn, has a standard deviation of 1.05 and the SD which shows that their answer is far apart from each other. This may be because the interviewed leaders have different personalities and characteristics. 
And according to the next number, the 30 leaders have courage because they are becoming models to their leadership colleagues and it has a high level (3.60) and has a standard deviation of 1.10. This SD means that the interviewees have answers that are far from each other. This is probably because they have different habits. Their high score in this area means they have their own perspective on being a model to their peers.

It can be seen in the following number in the table that the 30 interviewees will show a good outlook on life at the high level of 3.97 and standard deviation of 1.00. This SD means that the interviewees have similar perspectives. This can happen because every leader has good outlook on life. Their high level indicates that the leaders interviewed have a clear vision of their constituents.

In indicator number fourteen, it can be noted that the modeling of the interviewees leading other people in their community has a high level (3.83), and has a standard deviation of 1.12 which indicates that their relationships are far apart from each other. answer. This SD probably occurred because the interviewees did not have the same leadership scope and the people around them were also different. Their high marks in this area mean that their leadership in their respective constituencies is having a good influence on the people.

According to the final number in the record, the interviewed leaders maintain their high dignity in life has a very high level (4.23) which shows that the leaders are careful and good at maintaining their dignity. This in turn has a standard deviation of 1.22. It can be seen that their answers are far-fetched, perhaps because they are in different levels of leadership roles.

\subsection{Level of Dedication in Leadership (Post Survey)}

Table 3. Mean level of dedication in leadership (post survey)

\begin{tabular}{|c|c|c|c|}
\hline Indicators & Mean & SD & Interpretation \\
\hline 1. I am doing my duty to the best of my ability. & 4.57 & 0.63 & Very High Level \\
\hline 2. I have an appreciation for the role or calling that God has given me. & 4.63 & 0.81 & Very High Level \\
\hline 3. I want to help others as much as I can in times of need. & 4.40 & 0.93 & Very High Level \\
\hline $\begin{array}{l}\text { 4. I am focused on my role or task and nothing else can be a } \\
\text { distraction. }\end{array}$ & 4.03 & 0.61 & High Level \\
\hline $\begin{array}{l}\text { 5. I like to participate in meeting or gatherings where important things } \\
\text { are discussed. }\end{array}$ & 4.17 & 0.87 & High Level \\
\hline 6. I have joy in fulfilling my duties. & 4.43 & 0.77 & Very High Level \\
\hline $\begin{array}{l}\text { 7. I am contented with what I receive from my family, organization or } \\
\text { government. }\end{array}$ & 4.37 & 1.00 & Very High Level \\
\hline 8. I can live well as a member of the community. & 4.37 & 1.10 & Very High Level \\
\hline 9. I can express sufficiency in my life. & 4.30 & 0.92 & Very High Level \\
\hline 10. I have basic needs in life. & 4.13 & 1.11 & High Level \\
\hline 11. I am having personal growth. & 4.20 & 1.06 & High Level \\
\hline 12. I think I am becoming a model to my colleagues. & 3.80 & 0.92 & High Level \\
\hline 13. You can see a good outlook of life through me. & 4.20 & 0.76 & High Level \\
\hline 14. I am becoming a role model to other people in our community. & 3.93 & 0.94 & High Level \\
\hline 15. I have high dignity in life and I am maintaining it. & 4.33 & 0.92 & Very High Level \\
\hline Average & 4.26 & 0.89 & Very High Level \\
\hline
\end{tabular}

Legend:

$$
\begin{array}{ll}
\text { 4.21-5.00 } & \text { Very High Level } \\
3.41-4.20 & \text { High Level } \\
2.61-3.40 & \text { Average Level } \\
1.81-2.60 & \text { Low Level } \\
1.00-1.80 & \text { Very Low Level }
\end{array}
$$

It will be noted in the table above that the level of duty performance of social leaders to the best of their ability has increased. From 4.23 mean, it became 4.57. This happened when the researchers made them feel the language of love. The state of the sd has also become better. From 1.04, it has become 0.63, which means the leaders have a close answer. 
In the next number in the record it will be noted that the level of appreciation of social leaders in their God -given roles increased. From 4.37 mean, it became 4.63. This happened when the researchers made them feel the language of love. Also the state of the sd is much better. From 0.97 , it became 0.81 , which means the leaders have a much closer answer.

For the third number, it will be noted in the record that the level of helping others to the best of their ability has increased. From 4.37 mean, it became 4.40. This happened when the researchers made them feel the language of love. Along with this, the state of the sd has also become better. From 1.10, it became 0.93 , which means the leaders have a close -knit answer.

In the following count, it can be seen in the table above that the level of focus on the roles or activities of leaders in society without any other distraction increased. From 3.87 mean, it became 4.03. This happened when the researchers had already made them feel the language of love. The state of the sd has also become better. From 0.94, it became 0.61, which means the leaders have a much closer answer.

In the fifth number, it will be noted in the record that the level of willingness of social leaders to participate in meetings or gatherings where important matters are discussed has not changed. From 4.17 mean, it remained 4.17. This is probably because even though researchers have not yet made them feel the language of love they already desire it. In the state of sd it became better. From 1.05, it has become 0.87, which means the leaders have become closer to the answer.

In the following number it will be noted in the record that the level of joy in the performance of the role of leaders in society increased. From 4.27 mean, it became 4.43. This happened when the researchers made them feel the language of love. The sd, on the other hand, has also become a better state. From 1.05, it became 0.77 , which means the leaders 'response became close.

Seventh number, it will be noted in the record that the level that social leaders are content with what they receive from their family, organization or government has increased. From 4.07 mean, it became 4.37. This happened after the researchers felt the language of love in them. The state of the sd has also become better. From 1.28, it became 1.00, which means the leaders 'response became close.

In the following number, it will be noted that the level at which social leaders are able to live well as members of the community has increased. From 4.27 mean, it became 4.37. This happened when the researchers made them feel the language of love. In the state of sd, it is expected to increase. From 1.08, it became 1.10, for the reason that not all interviewed researchers leaders raised the indicator level in this segment.

In the ninth number, it will be noted in the table above that the level of expression of adequacy in the lives of social leaders has increased. From 3.97 mean, it became 4.30. This happened after the researchers made them feel the language of love. Also the state of the sd has become better as well. From 1.10, it became 0.92 , which means there is a close -knit answer that the leaders.

Tenth number, it will be noted in the record that the level at which the leaders in society have basic necessities in life has increased. From 3.97 mean, it became 4.13. This happened when researchers were able to feel the language of love in them. In the state of sd, it is expected to decrease. From 1.22, it became 1.11, which although their answers were still divergent reduced the level of divergence.

It will be noted in the table above at number eleven that the level of personal growth of social leaders has increased. From 4.00 mean, it became 4.20. This happened when the researchers made them feel the language of love. In the state of sd, it is expected to increase. From 1.05, it became 1.06, for the reason that not all interviewed researchers leaders raised the level on the indicator of this component.

Notice the next number in the table above, it can be seen that the level of social leaders who think they are becoming role models to their peers has increased. From 3.60 mean, it became 3.80. This happened after the researchers felt the language of love in them. Also the state of the sd has become better as well. From 1.10 , it has become 0.92 , which suggests that the leaders 'response is close.

In the thirteenth number, it will be noted in the table above that the level at which social leaders show a positive outlook on life has increased. From 3.97 mean, it became 4.20. This happened when 
researchers were able to make them feel the language of love. Along with this, the state of sd has also become better. From 1.00, it became 0.76, which means the leaders had a close response.

It will be noticed in the next number in the table above that the level at which social leaders become role models to other people around them has increased. From 3.83 mean, it became 3.93. This happened after the researchers felt the language of love in them. The state of the sd has also become better. From 1.12, it became 0.94 , and that means the leaders 'response was close.

In the final count, it will be noted in the table above that the level of high dignity in life and maintained by social leaders has increased. From 4.23 mean, it became 4.33. This happened when they were made to feel the language of love. Similarly the state of sd has also become better. From 1.09, it became 0.92, which means the leaders had a close -knit response

\section{Findings, Recommendation and Reflection}

\subsection{Findings}

- In accordance with the data that had been gathered by the researchers they found out that the love language of teachers is quality time.

- In accordance with the data that had been gathered by the researchers they found out that the love language of students is quality time.

- In accordance with the data that had been gathered by the researchers they found out that the love language of parents is quality time.

- In accordance with the data that had been gathered by the researchers they found out that the love language of politicians is quality time.

- In accordance with the data that had been gathered by the researchers they found out that the love language of religious group leaders is quality time.

- The leaders dedication level in leadership increase when the love language that they want inflicted to them.

\subsection{Recommendation}

It is a great opportunity for the researchers to contribute good thing for the society and leaders in Nagcarlan. That is why the researchers indicated on this paper their recommendation for teachers, students, parents, politicians, religious group leaders, and future researchers.

- Teachers - the researchers recommended to have time on finding the love language that they have and also the to the students because it will really help them in their leadership. They should also consider the importance of their work just like the appreciation of their students to them.

- Students - In despite to their load activities, the researchers also recommend to acknowledge their love language because it will help their self. In resemblance, they will show importance and inflict their love language to their teacher, so that their teacher will boost their dedication to teach and can educate their students more.

- Parents - the researchers recommended to acknowledge the love language of their children. They need to expand their understanding on inflicting love, because the children now a day is different than the previous generation. If they will acknowledge the love language of their children, they can guide their children in a right path.

- Politicians - In response to their love language, which is quality time, the researchers encourage them to reach their jurisdiction even by just going to the house of their people, when they have a remoted schedule. With the help of it, the citizen and the leaders can have a great connection, and as a leader it meets their own need to have a quality time. 
- Religious group leaders - the researchers suggested to make a symposium where the love language will be discussed. That way, the members can be opened about this matter, appreciate each other, and their spiritual group will flourish in number and quality.

- Future researchers - the researchers recommend to extend the scope of this study. With that, there will be more leader in the society will be included in the study.

\subsection{Reflection}

While doing this research, the researchers realize that love language helps to increase the willingness of the leaders to serve in school, church, town and even their homes. Likewise, when the love language of one another is fascinated, it helps to fill the gap between the leader and their led.

In the world that full of conflict, disagreement, self-discouragement and self-influx, it was right to discuss the concept of love language that is very helpful for everyone to know the right thing to do when inflicting love to others. Because of this research, researchers learned that the love language was able to encourage the leaders to perform leadership with high dedication to their duty. As students, the researchers have decided to always inflict the love language for our parents, teachers, leaders in the society and church because the researchers want to be part in reaching the right service. This research really helps not only at the present time but also to the next generation.

\section{Acknowledgements}

I dedicate this study to my parents Thelma A. Gadlan and Gilbert E. Gadlan for their support to me. Also to my siblings Jonalyn S. Roslin, Ma. Niña S. Carandang, Joseph A. Salinas, Ma. Wincess A. Gadlan and to Miracle A. Gadlan for their help in conducting and completing this study. I also dedicate this to Mr. Elymar A. Pascual, a teacher who has stood behind us, the researchers, and for continuously giving motivation and support for the development of this study. Lastly, to our Lord God, for His blessing and guidance to all our experienced as researchers for this study. Thank you very much.

\section{G.A.A.G}

It is my pleasure to offer this action research to my teachers who helped in this study to carry it out. As well as the people we interviewed and ask for their statement. I also dedicate this research to my parents Joven T. Bugia and Margarita C. Bugia, Sr. for they wholeheartedly supported this study. We have done this in believing that it will greatly help everyone as well as our society. Thank you very much.

\section{M.C.B.J}

I dedicate this research to my parents Emma G. Suzao and Eric C. Suazo. As well as to my brothers and sister, Emmerson John G. Suazo, Edward G. Suazo and Erika Mae G. Suzao because they have always been there to guide and support me. Also, to my friends and for people who always encouraging and supporting me. Thank you.

E.G.S

I dedicate this research to my parents Genny B. Burbos and Jose B. Burbos because of their everlasting support. Also to my brother, Joshua B. Burbos and sister, Lyka B. Burbos. In here, my friends, classmates, and people we interviewed were also included and specially the teacher who guided us to develop this action research, Mr. Elymar A. Pascual. This study will help every leader of a community or organization. Thank you very much.

J.B.B. 


\section{References}

Atienza, S. (2014). Mga Katangian Dapat Taglayin ng Isang Pinuno. Retrieved from https://prezi.com/oq-lyevsfiod/mga-katangiandapat-taglayin-ng-isang-pinuno/.

Bennis, W. (2016). "On Becoming a Leader", Limang Mahalagang Aral tungkol sa Leadership na kailangan mong Matutunan. Retrieved from http://yourwealthymind.com/five-essential-leadership-lessons-you-must-learn-now-tagalog/.

Blay, B. E. (2013). Elementary Statistics. Anvil Publishing, Inc.

Dela Peña, M. (2011). Tungo sa Pag-unlad, Mahusay na Pamumuno ang Kailangan. Retrieved from http://tuyoelem.cityofbalanga gov.ph/editorial/k12kba.

Gary C. (2018). What are the 5 Love Languages? Retrieved from https://www.sheknows.com/love-and-sex/articles/1059295/what-arethe-5-love-languages.

Gary C. (2010). What are the 5 Love Languages? Understanding Them Might Help Your Relationship Retrieved from https://www.sheknows.com/love-and-sex/articles/1059295/what-are-the-5-love-languages.

Gary C. (2015). How 'The Five Love Language' Can Improve your Relationship? Retrieved from https://lifehacker.com/how-the-fivelove-languages-can-help-you-win-at-relat-1734348074.

Gary C. (n.d.) The Five Love Language, Single $\quad$ Edition Retrieved from https://www.goodreads.com/author/quotes/622.Gary_Chapman

Kelly H. (n.d.). Five Love Language About Gary Chapman. Retrieved from http://www.5lovelanguages.com/

Ong, W. T. (2012). Paano maging lider? Retrieved from https://www.philstar.com/opinyon/2012/01/05/764563/paano-maginglider.

Proverbs $\quad 18: 21 . \quad$ (n.d.). Understanding the Five Love Language Retrieved from https://www.focusonthefamily.com/marriage/communication-and- conflict/learn-to-speak-your-spouses-lovelanguage/understanding-the-five-love-languages

Rivera, CA. M. (2012). Pinuno at Pamumuno (Leader and Leadership). Retrieved from https://www.scribd.com/doc/103966836/Pinunoat-Pamumuno-Leader-and-Leadership.

Tamano, A. A. (2009). Ang Tunay na Lider. Retrieved from https://oppositeofapathy.wordpress.com/2009/02/08/ang-tunay-na-lider/. 